\title{
阪大病院における高カロリー輸液用微旦元素注射剂の調製と品質試験
}

\author{
山路 昭, 倉田義昭, 藤井康子, 笠原伸元 \\ 紀氏沉恵, 大西 昇, 平岡栄一 \\ 大阪大学医学部付属病院薬郕部*
}

\section{Preparation and Quality Tests of Trace Element Injections for Intravenous Hyperalimentation}

\author{
AKIRA YAMAJI, Yoshiaki KURATA, YASUKo FujII, NobUYUKI KasahaRA \\ HIROE KISHI, NOBORU ONISHI, and EIICHI HIRAOKA \\ Department of Pharmacy, Osaka University Hospital*
}

(Received May 19, 1978)

\begin{abstract}
At Osaka University Hospital, trace element injections for intravenous hyperalimentation (IVH) were prepared and quality tests were conducted on their content uniformity and sterility. The composition of the injections was : IVH-Zn : Zn $20 \mu \mathrm{mol}$; IVH-M : Zn 20 $\mu \mathrm{mol}$, Mn $40 \mu \mathrm{mol}$, Cu $5 \mu \mathrm{mol}$, I $1 \mu \mathrm{mol}$. The ingredients were filtrated through $0.45 \mu \mathrm{m}$ membrane filter, filled and wet-sterilized at $121^{\circ}$ for 20 minutes. The content uniformity was determined by Atomic Absorption Spectrophotometry. The standard contents of the elements in the injections were determined in the range of 90 to $110 \mathrm{w} / \mathrm{v} \%$. All lots were negative to Sterility Test (J. P. IX).
\end{abstract}

Dudrick ら²によって臨床応用が確立された高カロリ 一輸液法 (Intravenous Hyperalimentation, 以下 IVH と略す）は，近年日本に执いても急速に発展普及してき たが, 本法では輸液のみで長期間患者の生命を維持し, さらに栄養状態の改善を目的としているために，投与さ れる薬剤は糖, 電解質, アミノ酸からなる基本液のほか に, ビタミン, 微量元素 (ミネラル) などの必須栄養素 の供給が不可欠である.

阪大病院薬剤部では, IVH 療法の進展とともに臨床面 での要望にこたえるべく, 簡便性と安全性を兼ね備えた IVH 製剂の開発を検討し，すでに糖・電解質基本液 ${ }^{2}$, IVH 専用ビタミン注射剤》飞ついて報告してきた。

微量元素 (亜鉛, 銅, マンガン, 鉄など) について は, 米国の高カロリ一輸液用製剤特にアミノ酸製剤中に 亜鉛含量が高く，その生体必要量が供 給されるとの報 告4)する. しかし日本に打ける高カロリ一輸液製剤全

* 大阪市福島区福島 1 丁目 $1-50 ； 1-50$, Fukushima 1-chome, Fukushima-ku, Osaka, 553 Japan
般にわたる著者らの実験結果のでは,これら微量金属の 含量はきわめて少く, 生体必要量の供給には不十分であ り,さらに臨床的にも亜鉛欠乏症》などの微量金属の欠 そにもとづく症例が報告されて括り，これらの微量金属 の投与が必須であることが明らかとなった．このような 見地から阪大病院薬剤部では医師の要請のもとに昭和 49 年から IVH 専用の 微量元素注射剂を院内製剂化し, 医 師により患者の体内レベルを追跡しながら適切量の投与 がルーチンに行われている. しかしこれらの微量元素の 生体必要量はきわめて少量であり, かつその過剩投与は 体組織への蓄積により中毒症をきたすお技それあるの で，その投与量を厳重にコントロールする必要がある. そこでこれら微量元素注射剂 (院内製片名: IVH-Zn 拈 よび IVH-M）の品質管理を目的として，原子吸光分析 法による簡便かつ正確な含量試験法を検討した. また IVH 施行患者へのリン酸イオンの補給を目的とするリン 酸二カリウム注射剤 (院内製剂名: IVH-P) の含量試験 についてもあわせて報告する. 


\section{実 臨 方 法}

\section{1. 試菲}

製剤用の原料試薬として $\mathrm{ZnSO}_{4} \cdot 7 \mathrm{H}_{2} \mathrm{O}, \mathrm{MnCl}_{2} \bullet 4 \mathrm{H}_{2} \mathrm{O}$, $\mathrm{KI}, \mathrm{K}_{2} \mathrm{HPO}_{4}$ は和光純薬試薬特級を, $\mathrm{CuCl}_{2} \cdot 2 \mathrm{H}_{2} \mathrm{O}$ は石 津製薬試薬特級を用いたが，その表示純度はいずれも 99\% 以上であった. 定量分析用標準試薬としては, 和 光純薬製原子吸光分析用標準液 (亜鉛, マンガン, 銅, カリウムいずれも $1,000 \mathrm{ppm}$ ) を使用した.リン酸イオ ンの滴定には容量分析用 $1 / 10 \mathrm{~N}$ 塩酸(和光純薬製) を用 いた.

\section{2. 製剂の調椠法}

IVH- $\mathrm{Zn}: \mathrm{ZnSO}_{4} \cdot 7 \mathrm{H}_{2} \mathrm{O} 5.75 \mathrm{~g}$ を注射用蒸留水（大塚 製薬) で全量 $1,000 \mathrm{~m} \ell$ に溶解し， $0.45 \mu \mathrm{m}$ のセルロース アセテート製メンブランフィルター（ミリポア社, 直径 $25 \mathrm{~mm})$ を通してろ過し， $1 \mathrm{~m} \ell$ ずつ分注後， $121^{\circ}, 20$ 分 間高圧蒸気隇菌した.

IVH-M: $\mathrm{ZnSO}_{4} \bullet 7 \mathrm{H}_{2} \mathrm{O} 2.875 \mathrm{~g}, \mathrm{MnCl}_{2} \bullet 4 \mathrm{H}_{2} \mathrm{O} 3.958 \mathrm{~g}$, $\mathrm{CuCl}_{2} \cdot 2 \mathrm{H}_{2} \mathrm{O} 0.426 \mathrm{~g}$, $\mathrm{KI} 0.083 \mathrm{~g}$ を注射用蒸留水にて 溶解し全量を $1,000 \mathrm{~m} \ell$ とし, $0.45 \mu \mathrm{m}$ メンブランフィル

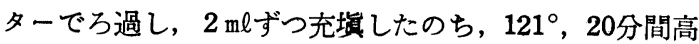
王蒸気滅菌した。

IVH-P (phosphate $16 \mathrm{mEq} / 20 \mathrm{~m} \ell$ ) : $\mathrm{K}_{2} \mathrm{HPO}_{4} 139.3 \mathrm{~g}$ を注射用蒸留水にて $2,000 \mathrm{ml}$ とし， $0.45 \mu \mathrm{m}$ メンブラン フィルターで減圧ろ過し, $20 \mathrm{~m} \ell$ ずつ充䁲後, $121^{\circ}, 20$ 分間高圧蒸気隇菌した。

\section{3. 原子吸光分析}

装置は日立 170-50 型を用い，フレーム方式により測 定した．測定波長は亜鉛 $213.9 \mathrm{~nm}$, 銅 $324.8 \mathrm{~nm}$ ，マン ガン $279.5 \mathrm{~nm}$ で原子吸光分析を行い, 測定值は 3 回の 平均值として求めた. カリウムは $766.5 \mathrm{~nm}$ の測定波長 で炎光法により測定した.

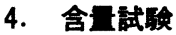

IVH 用微量元素注射剂 (IVH-Zn, IVH-M) の含量試 験は各ロットの検体 $1 \mathrm{~m}$ とを注射用蒸留水で 1,000 倍希釈 （10倍希釈を 3 回）し, 亜鉛，マンガン, 銅を前述の原 子吸光法で測定し, 標準液の検量線より各元素の濃度を 求めた. カリウムの測定には検液を10倍希釈し炎光法で 求めた。

IVH-P のリン酸イオン $\left(\mathrm{PO}_{4}{ }^{3-}\right)$ の定量には検体 $5 \mathrm{ml}$ を $2 \%$ 塩化ナトリウム液で全量 $20 \mathrm{ml}$ とし,メチルオレン ジを指示薬として $1 / 10 \mathrm{~N}$ 塩酸で滴定し, 次の計算式よ り求めだ).

$$
\begin{aligned}
& \mathrm{K}_{2} \mathrm{HPO}_{4}+\mathrm{HCl} \longrightarrow \underset{\mathrm{pH} 8 \sim 9}{\mathrm{KH}_{2} \mathrm{PO}_{4}+\mathrm{KCl}} \\
& \mathrm{pH} 5.0
\end{aligned}
$$

1 アンプルあたりの $\mathrm{K}_{2} \mathrm{HPO}_{4}$ の量 $(\mathrm{g})$

$$
=1 / 10 \mathrm{~N} \text { 塩酸滴定量 } \times 17.4 \times 10^{-3} \times 20 / 5
$$

\section{5. 無菌試駼}

第 9 改正日本薬局方に準じて行った．細菌試験にはチ オグリコール酸培地 I を, 真菌試験にはブドウ糖, ペプ トン培地を使用した。

\section{結果および考宷}

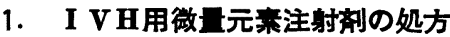

亜鉛などの重金属の生体必要量については不明な点が 多く, 特に IVH のような非経口投与量については現在 まだ研究中であるが，阪大病院では Wretlind ${ }^{8)}$ の提唱 している必要量を参考として, 表 1 に示す含量の製剤を 調製している. また，比較資料として Dudrick ${ }^{9)}$, Shils ${ }^{10)}$ の処方案および治験薬 (ミドリ十字製) の処方を記し た. 現在, 阪大病院第一外科の岡田らにより IVH 施行 時に拈ける微量金属の投与量に関して詳細な研究がなさ れているが,亜鉛については血清レベルの解析, 病態所見 などより成人患者 1 日あたり $60 \mu$ mole が必要であると の結果であり ${ }^{11)}$ ，亜鉛欠乏患者には IVH-Zn (20 $\mu$ mole) を 1 日 3 本投与している.また日本薬学会の「Hyperalimentation 用輸液に関寸る実態調查報告」(1978) ${ }^{12)} に よ$ ると 5 大学病院でトレースエレメントが製剤または処方 されているが，その処方は一般に亜鉛，マンガン，銅， ヨードを含み, 含量, 濃度は各大学によりそれぞれ異な っているのが現状である．鉄については患者の貧血症状 により市販の静注用鉄剂が投与されるが，IVH 専用鉄注 射剂の検討は未だなされていない，本院では1日必要量 の鉄（1〜2 mg）を含む IVH 用鉄注射剂の開発を目的 として，種々の鉄コロイドを調製し，輸液中での安定性 と bioavailability について現在検討中である.

なお，日本に打ける糖電解質製剂，アミノ酸製剤など に不純物として含まれる微量金属（亜鉛, 銅, マンガ ン. 鉄) の含量は著者らの測定結果ではすべて $0.1 \mathrm{ppm}$ 以下であり，米国の製剂4（特にアミノ酸製剂）にくら ベると約 1/100〜1/10 であった．また IVH 施行に使用 する点滴セット, フィルターからの溶出も全く認められ なかったので,これら重金属が不純物として混入，供給 される量は無視でき，したがって生体への投与量は微量 元素注射剂に含まれる量に限定されるとみてよい。

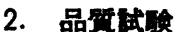

病院における院内製剤は少量, 多品目生産に特徵があ り，これらをすべて品質試験することは容易ではない。 しかし近年 GMP 実施にみられるごとく, 製凪の品質向 上が強く要求され，院内製剤にも GMP の概念の導入と 
表 1. IVH 用微量元素注射剤の処方

\begin{tabular}{l|c|c|c|c|c}
\hline \hline & \multicolumn{2}{|c|}{ 院内製剂 (阪大病院) } & $\begin{array}{c}\text { 治 験 薬 } \\
\text { (ミドリ十字 })\end{array}$ & DUDRICK ${ }^{9) *}$ & SHILS $^{10) *}$ \\
\cline { 2 - 3 } & IVH $-\mathrm{Zn}$ & IVH $-\mathrm{M}$ & & \\
\hline $\mathrm{Zn}$ & $1.3 \mathrm{mg}(20 \mu \mathrm{mol})$ & $1.3 \mathrm{mg}(20 \mu \mathrm{mol})$ & $1.012 \mathrm{mg}$ & $2.8 \mathrm{mg}$ & $2 \sim 4 \mathrm{mg}$ \\
$\mathrm{Mn}$ & & $2.2 \mathrm{mg}(40 \mu \mathrm{mol})$ & $1.341 \mathrm{mg}$ & $2.8 \mathrm{mg}$ & $1 \sim 2 \mathrm{mg}$ \\
$\mathrm{Cu}$ & & $0.32 \mathrm{mg}(5 \mu \mathrm{mol})$ & $0.534 \mathrm{mg}$ & $1.54 \mathrm{mg}$ & $1 \mathrm{mg}$ \\
$\mathrm{I}$ & & $0.13 \mathrm{mg}(1 \mu \mathrm{mol})$ & & & $70 \sim 140 \mu \mathrm{g}$ \\
$\mathrm{Fe}$ & & & & $1.4 \mathrm{mg}$ & $1 \mathrm{mg}$ \\
$\mathrm{Cr}$ & & & & & $15 \mu \mathrm{g}$ \\
$\mathrm{F}$ & & & & & $1 \sim 2 \mathrm{mg}$ \\
$\mathrm{Co}$ & & & $0.399 \mathrm{mg}$ & & \\
\hline
\end{tabular}

* 体重 $70 \mathrm{~kg}$ のVH施行成人患者の 1 日必要量(案)

実施が必要であろう．特に微量金属のような有効量と中 毒量の幅の小さい薬物では, 正確な含量と均一性が保証 された製剤が要求される.この点より昭和 52 年 5 月から 10 月まで阪大病院で製剤化した微量元素注射剤 (IVH$\mathrm{M}, \mathrm{IVH}-\mathrm{Zn}$ ) の全ロット（約 1 年分の使用量）について 含量試験および無菌試験を試みた。

亜鉛, マンガン, 銅の定量法としては EDTA 滴定法, 比色定量法などが一般的であるが，簡便かつ感度の高い 原子吸光分析法の適用を検討した．原子吸光法では各金 属濃度が $10 \mathrm{ppm}$ 以上では良好な検量線が得られず, 含 量試験には検体を注射用蒸留水で 1,000 倍希釈して測定 した. 各元素の標準液の検量線は, 図 1 亿示す濃度範囲 内では吸光度と濃度の間に原点を通る良好な直線性を示 し, 製剤希釈液の定量が可能となった。なおョード含量 については製剤原料として KI を用いているため, カリ ウムを測定することにより，間接的にヨードを定量する こととしたが，カリウムについては原子吸光法では再現 性が悪く, 炎光法を用いた結果 $0.1 \sim 0.5 \mathrm{ppm}$ の漶度範 囲で定量可能であった.

院内製剂 IVH-Zn および IVH-M 注射剤の 各ロット の原子吸光法による含量試験の 結果を表 2 と示した. IVH-Zn については 91.8〜102.5\% と比較的良好な結果 であったが，IVH-M では特にマンガンの含量が前者 3 ロットでやや低く，ロット番号 107725 では $88.7 \%$ の 値を示した．著者らは院内製剤の含量規格を一応，90〜 110\%（w/v） と定めたが，1ロットが院内規格で「不 適」と判定された.このマンガン含量の低値の原因とし て試薬の $\mathrm{MnCl}_{2} \bullet 4 \mathrm{H}_{2} \mathrm{O}$ の吸湿による純度低下が考兄ら れたので,新たに試薬を購入し, 開封後直ちに製凨に使用 しその後はデシケーター内に保管した. その結果では口 ット番号 107726, 107731 にみられるごとく, 105.6\%,
$110 \%$ の含量を示し院内規格に適合した。

IVH-P についてはりン酸含量を滴定法で測定したが, 表 3 亿示すように 94.0 95.5\% と非常に均一性のある 製鼡含量が確認された。これは原料である $\mathrm{K}_{2} \mathrm{HPO}_{4}$ の种 取量が多いので，その点での誤差が少いためと考えられ る.

IVH-Zn, IVH-M, IVH-P の製片工程に打ける分解な どによる含量低下は認められず，さらに保存中における 安定性試験でも, 6 カ月室温保存の結果では 3 製郕とも に含量低下は認められなかった。

な敃無菌試験については全ロットが「適」と判定され た.

以上の上うに，阪大病院薬剤部では IVH 用微量元素

表 2. 微量元素注射剤の含量試験の結果

IVH-Zn 注

\begin{tabular}{c|c|c|c}
\hline \hline ロット番号 & 含量(W/V\%) & ロット番号 & 含量 $(\mathrm{W} / \mathrm{V} \%)$ \\
\hline 057725 & 101.0 & 077725 & 101.0 \\
067707 & 102.5 & 087711 & 97.9 \\
077702 & 101.0 & 087722 & 91.8 \\
077706 & 97.9 & 097701 & 96.4 \\
\hline
\end{tabular}

IVH-M 注

\begin{tabular}{c|r|r|r|r}
\hline \hline \multirow{2}{*}{ ロット番号 } & \multicolumn{4}{|c}{ 含 } \\
\cline { 2 - 5 } & \multicolumn{1}{|c}{ 量 } & \multicolumn{1}{c}{$(\mathrm{W} / \mathrm{V} \%)$} \\
\hline 057727 & 96.4 & \multicolumn{1}{c}{$\mathrm{Mn}$} & \multicolumn{1}{c}{$\mathrm{Cu}$} & \multicolumn{1}{c}{$\mathrm{K}$} \\
\hline 087709 & 94.8 & 91.9 & 99.2 \\
107725 & 96.7 & 88.9 & 98.2 & 94.7 \\
107726 & 107.1 & 105.6 & 102.0 & 97.5 \\
107731 & 91.8 & 110.0 & 100.8 & 96.7 \\
\hline
\end{tabular}



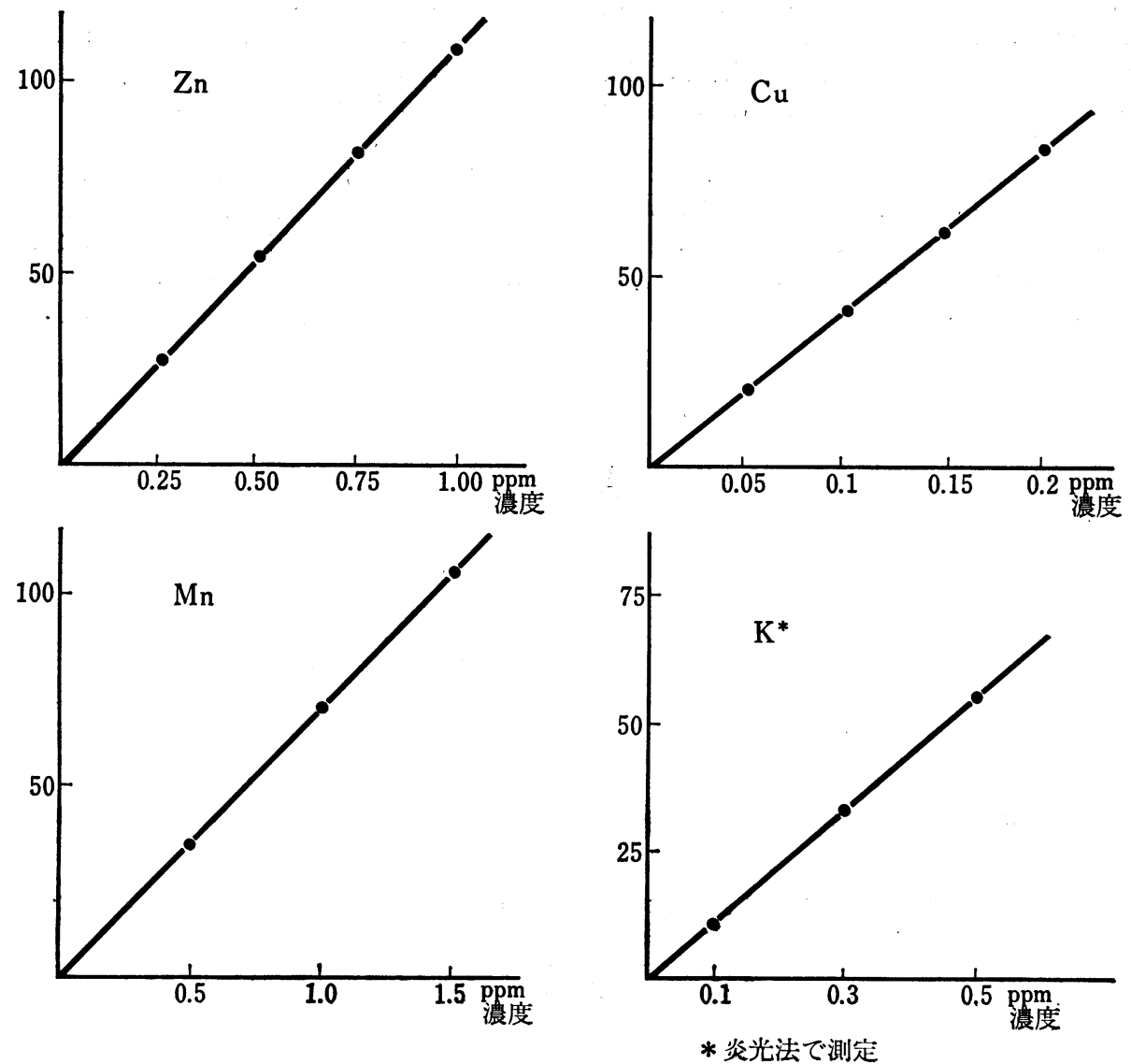

因 1. 原子吸光法での各元素の検量線

表 3. IVH-P の含量試醶の結果

\begin{tabular}{c|c}
\hline \hline 口 ト番号 & 含量 $(\mathrm{w} / \mathrm{v} \%)$ \\
\hline 057718 & 95.5 \\
057730 & 94.5 \\
077704 & 94.0 \\
087703 & 95.5 \\
087704 & 94.5 \\
087710 & 95.5 \\
087719 & 95.0 \\
087724 & 95.0 \\
087731 & 95.0 \\
\hline
\end{tabular}

注射剂の製剤化とその品質試験を実施している．本院で は 1 年間の製剤計画に基づき, 安定性の高いこれら注射 凨については約 1 年分の使用量をできるだけまとめて製 剂化し, 全ロットの品質試験を一度に実施できる方針で 行っているが, 原子吸光法は非常飞短時間 $(2 \sim 4$ 時
間）に全検体中の 4 元素の定量が可能であり，その簡便 性もあわせて院内製凧の含量試験法としては最適である と考える.

阪大病院莱剤部注射剤室では現在, 前述の注射剂以外 に約10品目の注射剤と 7 品目の点眼剤および約10品目の 外用滅菌液剤を院内で制剂化している。兵れらの品質試 験として定期的に無菌試験を実施し，さらに必要なもの については主薬の含量試験を高速液体クロマトグラフィ 一, 薄層クロマトグラフィー, 分光光度法などにより定 量または半定量を実施もしくは検討中である.

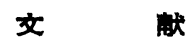

1) S. J. Dudrick, D. W. Wilmore, H. M. Vars, J. E. Rhoads : Surgery, 64, 134 (1968).

2）笠原伸元, 岡田 正：医学のあゆみ，86, 198 (1973).

3）山路 昭, 藤井康子, 佐藤健太郎, 笠原伸元, 紀 氏沉恵, 平岡栄一 : 薬剤学, 投稿中. 
4) C. A. Shearer, R. C. Bozian : Drug Intell. Clin. Pharm., 11, 465 (1977).

5）山路 昭, 倉田義昭, 藤井康子, 笠原伸元, 紀氏 沉恵, 平岡栄一, 高木洋治, 板倉文夫, 岡田 正 : 医学のあゆみ, 105, 934 (1978).

6) A. Okada, Y. Takagi, T. Itakura, M. Satani, H. Manabe, Y. Iida, T. Takagi, M. Iwasaki, N. Kasahara : Surgery, 80, 629 (1976).

7）高木誠司 : 定量分析の実蛤と計算, 共立出版, 第 2 巻, p153 (1961).
8) A. Wretlind : Nutr. Metabol., 14, 1 (1972).

9) S. J. Dudrick, J. E. Rhoads : J. Amer. Med. Ass., 215, 939 (1971).

10) M. Shils : Drug Intell. Clin. Pharm., 6, 385 (1972).

11）岡田 正, 池田義和, 龟頭正樹, 宗田滋夫, 高木 洋治, 板倉丈夫, 金 昌雄, 中川公彦, 山下 裕, 笠原伸元, 紀氏汎恵: 外科治療, 38, 177 (1978).

12）日本薬学会薬剤学委員会: Hyperalimentation 用 輸液に関する実㮩調查報告 (1978).

\section{《健保適用》}

\section{急性副堅皮質機能不全症及び ショック等の急性期に。}
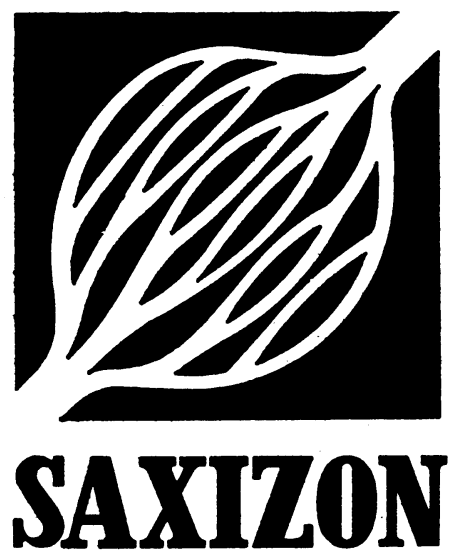

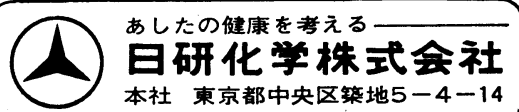

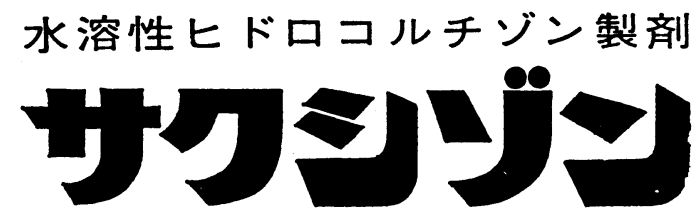

適応症

急性および慢性りウマ 千性疾患、急性副堅皮 啠機能不全症、急性過 敏症、喘息、播種性紅 斑性狼瘡、各種アレル ギー性疾患、ショック 状態における救急、各 種急性中毒 (薬物、自家 中毒等)、多形沴出性紅 斑、アジソン氏病
〈使用上の注意〉

用法、用量、使用上の 注意などは製品添付文 書をご参照下さい。

※医師等の処方せん指示に より使用すること。 